\title{
Nötr Maske, Nötrlük, Komedi
}

\section{Neutral Mask, Neutrality, Comedy}

\author{
Hazal İspirli1 ${ }^{1}$
}

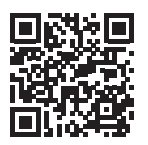

'Yüksek Lisans Öğrencisi, İstanbul Üniversitesi, Sosyal Bilimler Enstitüsü, Tiyatro Eleştirmenliği ve Dramaturji Anabilim Dalı, İstanbul, Türkiye

ORCID: H.I. 0000-0002-9251-6228

Sorumlu yazar/Corresponding author: Hazal İspirli,

İstanbul Üniversitesi, Sosyal Bilimler Enstitüsü, Tiyatro Eleştirmenliği ve Dramaturji Anabilim Dalı, İstanbul, Türkiye

E-posta/E-mail: hazal.ispirli@gmail.com

Başvuru/Submitted: 11.01.2021 Revizyon Talebi/Revision Requested: 21.01.2021

Son Revizyon/Last Revision Received:

21.01.2021

Kabul/Accepted: 15.02 .2021

\section{Atıf/Citation:}

İspirli, Hazal. "Nötr Maske, Nötrlük, Komedi" Tiyatro Eleştirmenliği ve Dramaturji Bölümü Dergisi 32, (2021): 169-188.

https://doi.org/10.26650/jtcd. 858415

\section{ÖZ}

Bu çalışma 20. Yüzyıl Avrupa tiyatrosunda fiziksel tiyatro araştırmaları yürüten Jacques Copeau ve Jacques Lecoq'un oyunculuk eğitimlerinde önemli bir yer tutan "nötr maske" çalışmalarından yola çıkarak teatral anlamda nötrlük kavramının oyuncuya açtığı olasılıklar üzerine bir okuma yapmayı amaçlıyor. Kavram; Philippe Lacoue-Labarthe'ın "aktif mimesis" ve "pasif mimesis" kavramları eşliğinde okunarak, başkalaşmaya, dönüşmeye, bir biçime ve kılığa bürünmeye (karakter ve rol yaratımına) doğru "aidiyetsiz bir ara alan" olarak ele alınacak nötrlük arayışının, oyuncuya sağladığı olanaklar tartışılacaktır. Bu bağlamda "aidiyetsiz ara alan" olarak nötrlük ve komedi arasında nasıl bir ilişki kurulabileceği sorusu üzerinde de durularak, "ikilik" ve "oyunbazlık" kavramları ile birlikte kılık değiştirmenin taşıdığı komedi potansiyeline odaklanılacaktır.

Anahtar Kelimeler: Nötr Maske, Mimesis, Kılık Değiştirme, Oyunbazlık, Komedi

\section{ABSTRACT}

This study is based on the neutral mask studies that have great significance within the acting studies of Jacques Copeau and Jacques Lecoq, who pursued physical theater studies in the 20th century European theater. The aim is to offer a reading on the possibilities that the concept "neutral" opens up for the actor. The possibilities that the search for the neutral implies for the actor will be explored as a ground without any identity or belonging -i.e., an interspace toward differentiation, transformation, taking shape, and character and role building - by approaching the term "neutral" with the active mimesis and passive mimesis of Philippe Lacoue-Labarthe. Further, by highlighting the relation as well between neutrality - as an inter-space without any identity or belonging - and comedy, the comedy potential that the act of taking theatrical form and disguise holds will be explored along with the concepts of "duality" and "playfulness."

Keywords: Neutral Mask, Mimesis, Theatrical Disguise, Playfulness, Comedy 


\section{EXTENDED ABSTRACT}

In its most basic meaning, the topic of this paper, neutral mask, is a means of discovering a body state that can prepare an actor for a play before beginning to create the character and the role.

As a start point for the actor, the neutral mask precedes the character and role building. In this context, it is an inter-space in which the actor is no longer in the actor's ordinary body and does not yet establish otherness. Why is the actor invited into a neutral degree before vitalizing the other? What are the possibilities for the actor, of which the term "neutral" might indicate?

Throughout the article, the possibilities that the term "neutral" and the above-mentioned inter-space can imply and the meanings they may give birth to in theatricality will be discussed in two distinct yet interrelated directions. First, the neutral state of the body of the actor will be examined as a quiet, relaxed and tensionless body study, in the sense of a state of openness and vigilance. In this regard, the relation among the presence of a tensionless body and the actor's listening to the surroundings and others will be discussed; and it will be noted that the tensionless body, as the actor's presence as a state of body, and as one of the main aims of neutral mask studies, never refers to a loose, non-energetic body. Neutral mask, by eliminating the face, helps the actor search for possibilities of expression and play in the actor's body. While the existence of a mask covering the face may first suggest a feeling of being concealed, it actually broadly reveals the body capabilities of the actor. That is, by distancing the actor from the ordinary and settled gestures, verbal expressions, and movement and acting habits, the mask provides a possibility for the actor to explore different bodily opportunities.

Within the acting studies, the mask gives the actor a body form and a possibility of play. Since the mask is unexpressed, it demands a body that is unexpressed from the actor. In this regard, it is a means to create a neutral state of body in which no expression and no character extension is yet formed. In fact, it was the collaborative work of Jacques Copeau and Albert Marque, that first designed the neutral mask, based on the concept of masks that have no expression used by the aristocracy during the 18th century. While this characteristic of no-expression of the neutral mask will establish the second direction of the article, the term "neutral" will also be read with Philippe Lacoue-Labarthe's active mimesis and passive mimesis as a state of inexpressive, neutrality where no character is yet formed, in order to discuss what the actor's quest for a ground without any identity or belonging corresponds to. According to Lacoue-Labarthe, the paradox is that the more the actor is nothing, the more the actor is able to be everything. With the neutral mask practices, the actor searches for a state of body in which no expression, adjective and characteristic that might refer to oneself or another is carried, toward being able to take the form of everything. The more the body of the actor is eluded from its belongings, the closer the actor is to taking the form of otherness, 
to playfulness, to the gift of mimesis as the creative and productive or formative force. This follows Dionysos, the source of Western theater, which has no pre-established form. Theatrical mimesis, for Lacoue-Labarthe, is the "the presentation of something other, which was not yet there, given or present."

The last part of the article explores how this very neutral ground where differentiation and transformation is possible, reserves a substantial capacity for the comedy, will be also explored. In this regard, the possible relation between neutral and comedy will be based on considering the comedy potential that the act of taking theatrical form or disguise holds. 
Maske, teatral olanın inşasında, oyuncunun kendi bedeninde bir başkasının kılığına bürünmesinin en somut araçlarından biri. Bir k1lık değiştirme unsuru olarak maske, oyuncunun, yaşamın içinde oyunu inşa etmesine ve teatral olanı kurmasına zemin hazırlıyor. Maske, "teatralliğin sembolü" diyor Mark Evans. ${ }^{1}$ 20. yüzyıl Avrupa tiyatrosunda, konvansiyonel tiyatro anlayışının yaşam ve oyun arasındaki çizgiyi bulanıklaştırdığı sahnelemelerin karşısında 'oyun'un ve 'teatral'liğin kendi dinamiklerinin açığa çıkabileceği tiyatro anlayışları ortaya çıkıyor. Teatral olan; oyuncunun yüz, mimik ve söz merkezli anlatısı yerine beden olanaklarıyla ortaya çıkardığı performansın anlatısına evrilirken kültürel ve toplumsal olarak bedeni algılayıştaki değişimin ${ }^{2}$ de etkisiyle bedenin oyun olanaklarının araştırıldığı "fiziksel tiyatro" araştırmaları önem kazanıyor. Maske; sahip olduğu biçim sayesinde oyuncuya, içine yerleşebileceği, kendisinden başka olan bir beden formu ve bu form içerisinde beliren beden olanakları ile araştırabileceği bir oyun zemini sunduğu için bu araştırmaların önemli bir unsuru halini alıyor.

Modern tiyatroda maskenin teatral bir unsur olarak sahnede yeniden kullanılmas1 birbirlerinden bağımsız bir şekilde, benzer zamanlarda Vsevolod Meyerhold ve Jacques Copeau ile gerçekleşiyor. ${ }^{3}$ Oyuncu, oyun maskeleri ile bedeninde bir başkasıyla karşıllaşmayı, 'şimdi ve burada', maskeye özgü olanları dinleyerek ve maskenin önerdiği forma ve oyuna teslim olarak gerçekleştiriyor. Copeau, oyuncunun maskeyi yüzüne takmasıyla birlikte sesinin tonunun dahi maske tarafından belirlendiğini; oyuncunun maskenin hakimiyetine girdiğini söylüyor. ${ }^{4} \mathrm{Bu}$ teslimiyet; bir tür esrime halinden farklı olarak, oyuncunun 'şimdi ve burada' her tür potansiyel oyun ve başkalık imkânına açık; uzamın tüm olanaklarına yanıt verebileceği ve boş alanı mevcudiyeti ile doldurabileceği uyanık bir beden algısına karşılık geliyor. Oyuncunun bir yandan kendisi olmayı sürdürürken bir yandan maskeyi icra etmesinin bir "ikilik" yarattığını söyleyen Eli Rozik ${ }^{5}$, maskenin teatral kullanımının tam da oyunculuğun bu ikili yapısı ile ilişkili olduğunu belirtiyor. ${ }^{6}$ Oyuncu mimetik eyleminde, her daim hem kendisi hem bir başkası.

Jacques Copeau ve Suzanne Bing'in Vieux Colombier'deki çalışmaları sırasında ortaya çıkan ve Jacques Lecoq, Jean Dasté gibi isimlerin yıllar içinde geliştirdiği nötr maske ${ }^{7}$ ise, bu ikiliğin ortaya çıkabileceği olası bir başlangıç zeminine dair bir arayış. Maiya Murphy nötr maske çalışmalarını; "belli teatral stillerin araştırllabileceği bir temel" 8 olarak ifade ediyor. Oyuncu için nötr maske çalışmaları; üzerinde çeşitli teatral biçimleri inşa edebileceği bir

1 Mark Evans, Jacques Copeau, (New York: Routledge, 2006), 135.

2 Simon Murray, Jacques Lecoq, ( New York: Routledge, 2003), 37-38.

3 Kerem Karaboğa, “Copeau'dan Terzopoulos’a Oyuncu ve Maske”, Maske Kitabı içinde, Ed. Kerem Karaboğa, Oğuz Arıcı (İstanbul: Habitus Yayıncılık, 2014), 95.

4 Copeau'dan aktaran: John Rudlin, Commedia dell'Arte: Oyuncular için El Kitabı, çev. Ezgi İpekli (İstanbul: Mitos Boyut Yayınları, 2000), 48.

$5 \quad$ Eli Rozik, "Mask and Disguise in Ritual, Carnival and Theatre”, South African Theatre Journal 11/1 (1997), 189.

6 A.g.e., 197.

7 Rudlin, Commedia dell'Arte: Oyuncular için El Kitabl, 48-49.

8 Maiya Murphy, Enacting Lecoq: Movement in Theatre, Cognition, and Life (Switzerland: Palgrave Macmillan, 2019), 51. 
zemin halini alıyor. Bu zemin, oyuncuya, 'oyun'un ve 'teatral' olanın talep ettiği beden halini keşfetmesine doğru bir olanak sağlıyor. Nötr maske çalışmaları; oyuncunun, ikiliğ $i$ ve oyunu yaratmasına doğru bir tür oyunbazlık arayışı. Oyunbazlık oyuncunun, boş alanda, yarattığı ikilikte ve ikiliğin oyununda açığa çıkıyor. Huizinga oyun kavramını kendi deyimi ile "biçim açısından ve kisaca" şöyle tanımlıyor:

(...) olağan hayatın dışında yer aldlğg hissedilen, özgür ve "kurmaca" ama yine de oyuncuyu içine çekme yeteneğine sahip bir eylem. Bu eylem bilhassa sınırlandırllmış bir zaman ve mekânda gerçekleşmekte, belirli kurallara uygun olarak, düzen içinde cereyan etmekte ve kendilerini gönüllü olarak bir esrar havasıyla çevreleyen veya alışılmış dünyaya yabancı olduklarını kılık değiştirerek vurgulayan grup ilişkileri doğurmaktadır. ${ }^{9}$

Oyun, kurmaca bir yapı. Kurmaca, ‘olağan’ ve ‘alışılmış’ kabul ettiğimiz dünyanın içinden 'bir başka' dünyanın yaratılması. Oyunda alışılmış, olağan kabul edilen hayatın dışında bir başka dünya kurulurken oyuncular, oldukları hallerden başka hallere, kılıklara bürünüyor. Buradan hareketle oyuncuları, kurmaca bir dünyanın kılık değiştiren özneleri olarak ifade etmemiz için bir imkân doğuyor. Aynı durum teatral oyun için de geçerli. Feral ve Bermingham teatralliği, "gündelik uzamın içinde bir yarıktan ortaya çıkan bir başkalık" olarak ifade ediyor. ${ }^{10}$ Bu yarı,, hali hazırda kendiliğinden süregiden gündelik hayatın içinde bir başkalığı açığa çıkararak alışılmış gündeliğin dışında bir uzam yaratıyor. Seyirci olarak hem burada olduğum hem başka bir dünyaya açıldığım, oyuncu olarak hem bu bedende olduğum hem de bu bedende başkasına dair bir dünya yarattı̆ğım gündelik dışı bir uzam. Vernant, Batı tiyatrosunun kökeni kabul edilen "kılık değiştirme, başkalaşma ve maske tanrısı"" Dionysos'un "belirdiği her yerde gündelik dekorun yerine fantastik bir sahne" kurduğunu belirtiyor. ${ }^{12}$ Mimetik eylem, oyuncunun kurmaca bir başka dünyanın icracısı olarak kendi bedeninde bir başkasının kılığına, biçimine, formuna bürünerek başkalığı vücuda getirmesi ile gerçekleşiyor. Bu anlamıyla mimetik eylem her daim bir ikilik barındırıyor. İkilik, oyuncunun şimdi ve burada vücuda getirdiği, kılığına büründüğü bir başkasıyla aynı anda, aynı bedende varlık gösteriyor olmasında. Oyuncu hem gündeliğin hem gündelikte bir anlık yaratılan bir başkalığın/bir başkasının bedenini taşıyor. "Oyuncu bir taşıyıcl”"13 diyor Tulû Ülgen. Zeynep Sayın'a göre oyuncular "başka birer dünyanın bedenleri". ${ }^{14}$

9 Johan Huizinga, Homo Ludens, çev. Mehmet Ali Kılıçbay (İstanbul: Ayrıntı Yayınları, 2015), 31.

10 Josette Feral ve Ronald P. Bermingham, "Theatricality: The Specificity of Theatrical Language." SubStance 98/99 (2002), 97.

11 Jean-Pierre Vernant ve Pierre Vidal-Naquet, Eski Yunan'da Mit ve Tragedya, çev. Sevgi Tamgüç, Reşat Fuat Çam, (İstanbul: Kabalcı Yayınları, 2012), 274.

12 A.g.e., 533.

13 Tulû Ülgen, Kurmaca, Yanılsama: Oyunculuk, Deneyim, Hakikat Arasında (İstanbul: SubPress Yayıncılık, 2018), 43.

14 Zeynep Sayın Kurmaca, Yanılsama: Oyunculuk, Deneyim, Hakikat Arasında adlı kitabının girişine yazdığı "Kurmaca/yanılsama: metnin düşündürdükleri" yazısında Anhui dansı, Luo diyagramı ve Nuo oyunlarını yorumluyor. Nuo oyunlarından hareketle oyuncuların başka dünyanın bedenleri olduğunu belirtiyor. Zeynep Sayın, "Kurmaca/Yanılsama: metnin düşündürdükleri”, Kurmaca, Yanılsama: Oyunculuk, Deneyim, Hakikat Arasında içinde (İstanbul: SubPress Yayıncılık, 2018), 7. 
Eugenio Barba oyuncunun beden tekniklerine ${ }^{15}$, "gündelik ve gündelik dışı beden teknikleri”" olmak üzere bir ayrım getiriyor. Bu ayrım bedenin gündelikte ve gösterim durumunda kullanımına ilişkin farklılıktan ortaya çıkıyor:

Bedenimizi gündelik yaşamdaki kullanışımız, gösterimdeki kullanışımızdan özde farklıdır. Gündelik tekniklerimizde (...) kıpırdarız, otururuz, bir şeyler taşırız, öperiz, bir fikre katılıp katılmadiğımızı bildiririz ve bunların hepsini (...) kendiliğinden ama aslında kültürel olarak belirlenmiş hareketlerle yaparı (...) Oyuncunun sahne yaşamı ya da biosunu yöneten ilkeleri bulmada ilk adım, bedenin gündelik tekniklerinin karşısındaki gündelik-dışı olanları kavramaktır. Gündelik koşullanmaları pek ciddi saymayan teknikler, gösterim durumunda gündelik tekniklerin yerini alır. Oyuncular bu gündelik-dışı tekniklerden yararlanır. ${ }^{16}$

20. yüzyılda fiziksel tiyatro araştırmaları yürüten Jacques Copeau ve Jacques Lecoq için tüm performansların başlangıç ve bitiş noktası oyuncunun bedeni. ${ }^{17}$ Copeau ve Lecoq tiyatro çalışmalarında; bedenin taşıdığı oyun potansiyellerinin peşinden giderek oyuncunun oyuna dair yaratıcılığını güçlendirecek araştırmalar yürütüyor. Copeau'nun oyunculuk eğitiminde oyuncu, bir çocuğun oyunla kurduğu ilişkideki bağı yeniden hatırlamanın keşfinde ${ }^{18}$, çocukların oyunbaz yaratıcılığının ilhamında. ${ }^{19}$ Lecoq, pedagojisinin “oyuncunun oyun oynamaktan zevk aldı̆̆ bir tiyatronun ortaya çıkışına zemin hazırlamayı" hedeflediğini söylüyor. ${ }^{20}$ Oyuncunun oyuna dair yaratıcı potansiyelinin ortaya çıkması için ise hem Copeau hem de Lecoq için, bir hazırlık süreci, bir başlangıç noktasına ihtiyaç var. Copeau ve Lecoq için farklı teatral biçimlerin talep ettiği farklı oyun seviyelerinin başlangıç noktası nötr seviye, bir başka deyişle oyuncunun nötr maske seviyesindeki beden hali. Nötr maske, oyuncu bedenini nötr seviyeye taşıyacak bir yardımcı.

Nötr maske fikri ilk olarak Copeau'nun öğrencileriyle yaptığı bir çalışma esnasında fiziksel anlamda gerginlik yaşayan bir oyuncunun yüzünü mendille kapaması ve yüzü elimine olan oyuncunun rahatladığını fark etmesiyle ${ }^{21}$; oyuncuların bedenleriyle ilişkisini kuvvetlendirmek, bu anlamda yüzü ifadenin merkezi olmaktan çıkarıp ifadeyi bedende aramaya dair bir arayış olarak ortaya çıkıyor. ${ }^{22}$ Maske ilk takıldığında oyuncuya gizlenmişlik hissi verse de aslında

15 "Beden teknikleri” kavramından ilk olarak Fransız antropolog Marcel Mauss 1914 senesinde Paris Psikoloji Topluluğunda bahsetmiştir. Eugenio Barba ve Nicola Savarese, Oyuncunun Gizli Sanatı Tiyatro Antropolojisi Sözlüğ̈̈, çev. Ayşın Candan, Tarhan Onur, Aslı Seven (İstanbul: Bilgi Üniversitesi Yayınları, 2017), 310.

16 A.g.e., 14.

17 Murray, Jacques Lecoq, 5.

18 A.g.e., 30.

19 Evans, Jacques Copeau, 60-61.

20 Jacques Lecoq, Şiirsel Beden, çev. Mine Çerçi (Ankara: Nota Bene Yayınları, 2015), 117.

21 John Rudlin, "The Quest For Sincerity”, Twentieth Century Actor Training içinde, Ed. Alison Hodge (New York: Routledge, 2000), 72.

22 Copeau'ya göre oyuncuların “kanları donmuş halde” çünkü oyuncular bir kol kaldırma hareketinde dahi kaskatı kesilmekte. Copeau, bu anlamda, oyuncuların bedenleriyle kurdukları ilişkinin zayıflığına vurgu yapıyor., A.g.e., 57-58. 
oyuncunun bedenini ortaya çıkaran bir unsur. ${ }^{23}$ Yüzün tamamını kaplayarak oyuncuyu, gündelik hareket ve eyleme alışkanlıklarından, ezberlenmiş jestlerden, klişelerden ve söz merkezli ifade biçimlerinden uzaklaştıran maske; oyuncunun beden olanaklarını keşfetmesine dair bir imkân yaratıyor. Teatral bir unsur olarak maske, oyuncuyu gündelik uzamın içinde yaratılan gündelik dışı bir uzama doğru taşıyacak bir dayanak noktası oluşturuyor. Nötr maske ile oyuncu, karakter ve rol yaratımına geçmeden evvel, gündelik bedeninde bir çalışma gerçekleştirerek gündelik dışı bedenini inşa ediyor. Copeau için nötr maske, jest ve hareketleri sadeleştiren, ifadeyi yüz ve mimikler yerine fiziksel olanda arama ihtiyacı yaratan, hareketin ve hareketsizliğin ilişkisini somutlaştıran, oyuncunun yürümek, oturmak, ayağa kalkmak gibi basit fiziksel hareketlere odaklanmasını sağlayan bir dayanak noktası. ${ }^{24}$ Oyuncunun nötrlügü; "sükûnetin veya sakinliğin, veya gevşemenin/rahatlamanın veya sessizliğin veya sadeliğin seviyesi." 25 Oyuncu nötr maske ile bedenindeki gerilimi, "kaskatı, kanları donmuş hal' ${ }^{26}$ rahatlatarak, nefes alan, sakin, gerilimsiz, sükûnetli bir beden halini araştırıyor. Sükûnetli bedenin gerilimsizliği, oyuncunun beden enerjisini yavaşlattığı gevşek bir hal değil; içinde taşıdığı canlı ve dolu enerji, bedenin hem gerilimli hem gerilimsiz hali. Katsuko Azuma'nın ustasından aktardığ 1 "çelik ile pamuk" imgesi; oyuncunun bedenindeki gerilim ve gerilimsizliğin eş zamanlı varoluşunu açıklar nitelikte:

Ustam, her oyuncu kendi güç merkezini bulmalıdır, derdi. Bu, merkezinde çelik bir top bulunan bir üçgen olarak düşünülmeli. Ü̧̧genin tepesi anüs 'te, öteki iki açısı ise göbek düzeyinde kalçanın iki köşesindedir. Oyuncu dengesini bu güç noktasında odaklamayı başarmalıdır. (...) Ama bu güç, gerilim ya da şiddetle eş anlamlı değildir. Ustam çelik topun kat kat pamukla kaplı olduğunu, bu yüzden derin merkezinde sert bir şeyi gizleyen yumuşak bir şeye benzediğini söylerdi. Oyuncunun hareketleri yavaş ve yumuşak olabilir. Bir meyvenin çekirdeğini sakladığı gibi gücünü saklayabilir. ${ }^{27}$

Oyuncunun nötr maskeyle araştırdığı gerilimsiz beden hali, gevşek ve enerjisiz bir rahatlığa tekabül etmiyor. Oyuncu nötr maske ile çalışmalarında nötr bir seviyenin peşindeyken her daim oyunun talep ettiği enerji seviyesini taşımanın peşinde. Barba enerjiyi şöyle tanımlıyor:

Onu daha çok dış itkilerle, kas ve sinirsel etkinlik fazlasiyla ilintilendiririz. Ama enerji aynı zamanda yakınlık içeren, hareketsizlik ve sessizlik ortamında nabız atışları duyulan, uzamda dağılmaksızın zaman içinde akan çekinik bir güçtür. Enerji çoğu kez baskıcı ve şiddet içeren davranış örneklerine indirgenir. Ama aslında oyuncunun belirleyebildiği, uyandırıp biçimlendirebildiği kişisel bir ısı yoğunluğudur. Her şeyden önce araştırılıp keşfedilmesi gerekir. ${ }^{28}$

23 Jacques Lecoq, Theatre of Movement and Gesture (New York: Routledge, 2009), 105.

24 Evans, Jacques Copeau, 135-136.

25 Rudlin, "The Quest For Sincerity", 70.

26 A.g.e., 57.

27 Katsuko Azuma'dan aktaran: Barba, Oyuncunun Gizli Sanatı Tiyatro Antropolojisi Sözlüğ̈̈, 126-128.

28 A.g.e., 171 
Ülgen, sükûnetin donukluk, uyuşmuşluk değil tam tersi bir genişleme hali olduğunu söylüyor. ${ }^{29}$ Oyuncu kendi bedeninde sükûneti, sakinliği, sessizliği sağladığında etrafa açılmaya, genişlemeye, etrafi duymaya ve dinlemeye başlıyor. Tam da bu sebeple nötr maske çalışmaları ile oyuncu uzamdaki etkilere açık olabilecek ve onlara tepki verebilecek uyanıklıkta canlı, yaşayan bir beden inşa ediyor. Lecoq, nötr maske çalışmaları ile oyuncunun uzamdaki varlığını geliştirdiğini söylüyor. ${ }^{30}$ Bedeni sarmalayan uzam hem şimdi ve buradaki mekân, oyun alanı hem de tüm dünya. Oyuncu duymaya, dinlemeye başladıkça bedeni çevreleyen dünyanın, potansiyel oyun alanının, tüm etkilerine cevap verebileceği, değişip dönüşebileceği; oyuna, oyunbazlığa hazır bir beden seviyesini araştırıyor.

Lecoq için nötr maske "denge halinde olan, tüm bedene sükûnetin fiziksel duyumunu öneren ve nötr denilen bir yüz." "31 Oyunculuk çalışmalarında maske; oyuncuya içine yerleşebileceği bir beden formu, biçimi ve dolayısıyla oyun imkânı sunuyor. Maskede sivri bir burun, fazla kırışık bir alın, yuvarlak oval bir çene gibi vurgular; oyuncu bedeninin alabileceği biçimlere dair ipuçları veriyor. Oyuncu icra edeceği maskenin formlarını; o formlara ait olanları dinliyor, bedenini o formların uzantısı olabilecek biçimlere dönüştürüyor ve o formların uzamıyla açılan bir başkalıktaki oyun olanaklarını araştırıyor. Öyleyse üzerinde herhangi bir ifadenin bulunmadığ Lecoq, nötr maskenin özel bir ifade veya karakteristik taşımadığını; gülme, ağlama, üzülme ya da mutluluk belirtmediğini yalnızca sessizlik ve sakinliğe dayandığını söylüyor. ${ }^{32}$ Copeau için nötrlük "bir ifade için çıkış noktası”. ${ }^{33}$ Oyuncunun nötrlük arayışı; kendisini çevreleyen dünyayı bedeniyle algılamasına doğru; gerilimsiz, sakin, dengede, sükûnetli bir beden inşasının yanında aynı zamanda henüz bir ifadenin, karakterin oluşmadığı ifadesiz bir beden hali olarak karşımıza çıkıyor. Nötr maske ile oyuncu, ifadesizliğin oyununu araştırıyor. Nitekim nötr maskenin ilham kaynağı; 18. yüzyıla kadar aristokrasi sınıfının sokakta kimliklerini gizli tutmak için taktığı ifadesiz maskelere dayanıyor. ${ }^{34}$

Nötr maske ilk olarak asil (noble) maske ${ }^{35}$ adıyla Copeau ve Albert Marque'ın ortak çalışması ile anonim kalmak için kullanılan maskelerden hareketle tasarlanıyor. ${ }^{36}$ Anonimliği kişinin kim olduğu anlaşılamayacak kadar herhangi biri ve aynı anda bir hiç kimse olması durumu şeklinde ifade edersek; nötrlük arayışında karşımıza bir kimseyi/bir şeyi imleyecek herhangi bir ifadenin olmadığ ifadesiz bir maske, beden ve zemin çıkıyor. Bu anlamda, nötr maske yaratılma gayesi

29 Ülgen, Kurmaca, Yanılsama: Oyunculuk, Deneyim, Hakikat Arasında, 17.

30 Lecoq, Siiirsel Beden, 54.

31 A.g.e, 52.

32 Lecoq, Theatre of Movement and Gesture, 105.

33 Rudlin, "The Quest For Sincerity", 70.

34 A.g.e., 72.

35 “(...) Jean Dasté ile çalışan Jacques Lecoq daha sonra bu maskeyi geliştirip adına nötr maske diyecektir." Lecoq, Şiirsel Beden, 187.

36 Murray, Jacques Lecoq, 31. 
ile kimseye ait olmayan bir nitelik(sizlik) taşıyor. Sayın'a göre "niteliksizliğe, ancak kendi mekânına dair bütün özelliklerden feragat edildiği zaman öykünülebilir." ${ }^{37}$ Oyuncunun nötrlük arayışı, bir mümkünlüğü zorlayarak kendini veya bir başkasını imleyecek herhangi bir ifade, nitelik, sıfat taşımadığı, kendine dair bütün özelliklerden feragat ettiği bir beden seviyesinin neye karşı1ık gelebileceğine dair bir araştırma. Bu anlamda Doğu tiyatrosu'nda üzerinde sıkça durulan gündelik dışı bedenin "ifade öncesi durum"unu anımsatıyor:

Sahne varlı̆̆ının belirli bir niteliğinin gözlemi, gündelik teknikler, ustalık teknikleri ve gündelik-dışı teknikler arasında bir ayrım yapmamıza yol açtı. Oyuncuyu ilgilendiren, bu sonunculardır. Herhangi bir şeyi betimlemeden ya da anlatıma girmeden önce oyuncunun yaşamın belirleyen bunlardır. Bunu kabul etmek bir Batılı için hiç kolay değildir. Oyuncunun sanatında, onun, hem herhangi bir şeyi betimlemez ya da bir anlam taşımazken hem de canlı varlık gösterir olduğu bir düzey nasıl mümkün olabilir? ${ }^{38}$

Oyuncunun nötrlük arayışı, sahnenin talep ettiği mevcudiyeti; oyuncunun sahnede canlı, yaşayan bir varlık olabilmesini taşıyan bir oyuncu bedenine doğru bir yolculuk. Oyuncu için nötrlük, bir karaktere doğru henüz ifadenin başlamadığı, oyuncunun bedenini ve beden hareketlerinin dramatik ifade gücünü ${ }^{39}$ ve olanaklarını keşfettiği, gündelik ve gündelik dış1 arasında bir yerde konumlanıyor. Barba, oyuncunun gündelik ve gündelik dışı beden uzamının arasında yer alan beden halinin, oyuncu için neyi işaret ettiğini No tiyatrosundan bir örnekle anlatiyor:

(...) Japon tiyatro biçimlerinin çoğunda oyuncuların gündelik bedeni ile oyun kişisinin hayali bedeni arasinda bir ara düzey algllanabilir. Basit bir örnek verelim. Bir No oyuncusu, gösterim sona erdiği için sahneden ayrılırken çok özel bir davranış sergiler. Çok ă̆ır hareket eder. Çıkışı, gösterimin bütünü içinde yer alırmış gibidir. Artık karakterin içinde değildir, çünkü karakterin eylemi sona ermiştir. Ama kendi gündelik gerçekliği içinde de değildir. Bir ara durumdadır. Bir anlamda kendi yokluğunu oynamaktadır. ${ }^{40}$

Gündelik beden ve gündelik dışı bedenin yanı sıra, ikisinin arasında oyuncunun kendi yokluğunu oynadığı bir ara alanda Barba'nın "yapıntı beden"41 olarak ifade ettiği bir beden hali mevcut. Yapıntı beden; oyun kişisi ve rol kişisi arasında, oyuncunun artık gündelik uzama ait olmadığı fakat henüz gündelik dışına ait bir başkalığı da yaratmadığı bir beden yapılanması. Oyuncu için nötrlük arayışı da tıpkı "yapıntı beden” gibi gündelik ve gündelik dışı arasında oyuncunun kendi yokluğunu oynadığı bir ara alana karşılık geliyor. Ülgen, oyuncunun kendinden başkasına doğru açıldığı ara alanı "hareket ve dönüşüm alanı" olarak ifade ediyor. ${ }^{42}$ Oyuncu, gündelik ve gündelik dışı arasında bir ara alanda, hareket ve eylemliliğiyle bir başkasına

37 Zeynep Sayın, Imgenin Pornografisi (İstanbul: Metis Yayınları, 2015), 272.

38 Barba, Oyuncunun Gizli Sanatı Tiyatro Antropolojisi Sözlüğ̈̈, 14.

39 Evans, Jacques Copeau, 135.

40 Barba, Oyuncunun Gizli Sanatı Tiyatro Antropolojisi Sözlüğ̈̈, 56.

41 A.g.e., 56.

42 Ülgen, Kurmaca, Yanılsama: Oyunculuk, Deneyim, Hakikat Arasında, 118. 
dönüşmeye, 'o’nun kılığgna bürünmeye doğru, kendi yokluğunu vücuda getirdiği ne kendisi ne bir başkası olduğu bir bedenin izinde. Oyuncunun nötrlüğü, başkalığın biçimine, kılığına bürünmeye doğru ne kendisi ne bir başkası, "genel bir nötr varoluş halinden başka bir şey sergilenmediği durumun adı. "’3

Vernant, Bakkhalar ${ }^{44}$ oyunundan hareketle Dionysos'un her an başka bir k1lıkta tezahür etmesine ilişkin şunları söylüyor:

(...) Pentheus yabancıya sorar: "Tanrı'yı net gördüğ̈̈nü söylüyorsun. Ne kllıkta göründü??" Olayı tüm berraklığıyla gören adama göre, diğer varlıklar şeyler gibi Tanrlların da belirli bir şekli, doğasıly ve kimliğiyle örtüşen görülür bir veçhesi olmalıdır. Yabancı cevap verir: "Istediği kllı her neyse" ve ekler "ona emir verecek halim yoktu." Dionysos tezahür ettiğinde, zuhur ediş biçimi [kılı̆̆g] konusunda uyması gereken hiçbir kural yoktur. Çünkü Tanrı'nın sonsuza dek içine hapsedebileceği önceden hazırlanmış hiçbir biçim yoktur. Trajik metin maskeli Tanrı'nın bu bilmecemsi veçhesine ilişkin bu belirsizlik halesini birçok yerde vurgular: bu Tanrl (ya da yabancl) "her neyse" ya da "her ne olacaksa" odur.4

Önceden belirli herhangi bir biçime, forma, niteliğe sahip olmayan Dionysos her an bir başkalığın kılığında tezahür ediyor. Philippe Lacoue-Labarthe, "Diderot: Paradox and Mimesis" "46 makalesinde tartıştığı üzere; mimetik eylemi, bir başka deyişle oyuncunun paradoksunu şöyle belirtiyor: oyuncu "ne kadar hiçbir şeyse o kadar her şey olmaya kadir". ${ }^{47}$ Mimetik eylem; her an her şeyin kılığına, her şeyin biçimine bürünebilmek için kılıksızlaşan, bu anlamda hiçbir niteliği sahiplenmeyen, hiçbir aitliği taşımayacak kadar “öznesizliğe gönüllü”48 bir oyuncu talep ediyor. Oyuncunun her kalıbın şeklini alması için "ne soğuk, ne sıcak, ne ă̆ır, ne hafif" olması, her akorda girebilmesi için kendine ait bir akordu taşımaması halinden söz ediyor Diderot. ${ }^{49}$ Oyuncu oynayacağı karakterin, rolün, şeyin kalıbına yerleşen; kendi halinde kendine özgü bir formu, niteliği, biçimi bulunmayan ancak oyunla, oynadıkça şekle, biçime giren, kılık değiştiren oyunbaz bir varlık. Oyunbazlık; aidiyetsiz bir ara alanın, bir yokluğun, bir boş alanın içinde her an açığa çıkmaya kadir bir potansiyel. Lacoue-Labarthe'a göre teatral mimes, doğada verili olmayan, hali hazırda bulunmayan "başka bir şeyin temsili" ${ }^{50}$, henüz bulunmayan fakat oyuncu tarafından yaratılan, yoktan varolan bir mimetik eylem, bir "aktif mimesis". ${ }^{51}$ Lacoue-Labarthe; bu tür bir mimesisi, "üretici bir güç" ya da bir "poiesis" olarak

43 Lecoq, Siiirsel Beden, 190.

44 Euripides, Bakkhalar, çev. Sabahattin Eyüpoğlu (İstanbul: İş Bankası Kültür Yayınları, 2010).

45 Vernant, Eski Yunan'da Mit ve Tragedya, 529.

46 Philippe Lacoue-Labarthe, "Diderot: Paradox and Mimesis", Typography: Mimesis, Philosophy, Politics (Stanford: Stanford University Press, 1989), 248-266.

47 A.g.e., 260.

48 Ülgen, Kurmaca, Yanılsama: Oyunculuk, Deneyim, Hakikat Arasında, 255.

49 Denis Diderot, Aktörlük Hakkında Aykırı Düşünceler, çev: Sabri Esat Siyavuşgil (İstanbul: Çağdaş Matbaacılık Yayınc1lı, 2000) 60-61.

50 Lacoue-Labarthe, "Diderot: Paradox and Mimesis", 257.

51 A.g.e., 264. 
ifade ediyor. ${ }^{52}$ Yunanca poiein "yapmak", aynı kökten türeyen poiesis ise "yaratıcı edim" anlamına geliyor. ${ }^{53}$ Oyuncu, aktif mimetik eylemin yaratıcısı.

Oyuncu bir yaratıcı. Oyuncu; aktif mimesise doğru, kendi yokluğunda olduğu bir ara alanda her şeyde yer edinebilme, her şeyin uzamına girebilme, her şeyin formunu alabilme imkânına doğru yersizleşmeye, kökensiz kalmaya gönüllü olan. Bu anlamda oyuncu, önce kendini ve bir başkasını imleyecek ifadelerden feragat ediyor, mülksüzleşiyor. Oyuncu, gündelik ile gündelik dışı arasında bir ara alanda, önce her an her şeyin kılığına bürünebilecek bir "niteliksizliği” araştırıyor, sonra sonsuz olasılıkta bir başkasının niteliklerine, hikayesine yerleşme imkânı ediniyor. Ülgen sükûneti "bir yerin sakini olma, bir yere yerleşme" "54 olarak ifade ediyor. Foley Sherman, oyuncunun nötr maske ile gerçekleştirdiği mimetik eylemin ne olduğunu şöyle yorumluyor: "nötr maske ile mimesis başkalı̆̆ tekrar etmez, temsil etmez veya başkaliğın yerine geçmez fakat öğrencinin kendini yerinden edilmiş halde bulmasına alan açar." ${ }^{55}$ Oyuncunun nötrlük arayış1 hem oyuncunun uzamdaki mevcudiyetini genişleterek uzama ve bedenine yerleşmesi hem de her şeyin kılığına bürünmeye doğru hiçbir niteliği sahiplenmeyecek bir beden halinin peşinde olması, bu anlamda kendini yerinden etmesi. Lecoq'a göre oyuncu bedeni, başlangıç noktası olarak nötr seviyeyi yakaladığında özgürleşiyor. ${ }^{56}$ Oyunbazlığı, oyuncunun kendini 'tarihsel' (değişebilir, olanaklı, herşeye ait, herşey olabilmeye kadir) görebilme becerisi, bu beceride açılmakta olan bir hürriyet olarak aniyor Ülgen. ${ }^{57}$

Nötr kelimesi, "birinden yana olmayan, tarafsız, bîtaraf” anlamlarına geliyor. ${ }^{58}$ Oyuncu; bir başkasını vücuda getirmeye, bir başkasının kılığına bürünmeye doğru bir ara alanda, "tüm başkalıklara aidiyet anlamında tarafsız" ${ }^{59}$ Sayın, bu anlamdaki tarafsızlığın; nihayetinde kendini dahi tercih etmemek, kendini yıkmayı göze alabilmekle ilişkili olduğunu söylüyor. ${ }^{60}$ Bir başka deyişle oyuncu mevcudiyetini, vücuda getirişte, "ek-stasis" (vecd) halinde kendinden dışarı çıkarak gerçekleştiriyor:

52 A.g.e., 256.

53 Richard Sennett, Ten ve Taş, çev. Tuncay Birkan (İstanbul: Metis Yayınları, 2014), 73.

54 Ülgen, Kurmaca, Yanılsama: Oyunculuk, Deneyim, Hakikat Arasında, 17.

55 Foley Sherman'dan aktaran: Murphy, Enacting Lecoq: Movement in Theatre, Cognition, and Life, 143.

56 Lecoq, Siirsel Beden, 53.

57 Ülgen, Kurmaca, Yanılsama: Oyunculuk, Deneyim, Hakikat Arasında, 255.

58 "Nötr" kelime anlamı, İnternet erişimi: http://www.lugatim.com/s/n\%C3\%B6tr

59 Ülgen, Kurmaca, Yanılsama: Oyunculuk, Deneyim, Hakikat Arasında, 117.

60 Sayın, Imgenin Pornografisi, 268. 
(...) varlık dediğimiz şey, gaybdan, gayb içinden an be an zuhur eden, başka bir ifadeyle hiçlikten dışa vurarak görünüşe gelen, yani "ex" olan, dışa duran bir şeydir. Almanca ve Ingilizce'de gördügümüz bu anlam ilişkisinin benzerini Arapçada takip etmek mümkün görünüyor: Mevcut, vücut ve vecd sözcükleri arasındaki kökensel ilişki existence, exist ve exctasy sözcükleri arasindaki ilişkiye çok benzemektedir. Bu etimolojik ilişkiye yakından baktığımızda mevcudiyet yani existence, mevcut yani exist olma hali, ancak ve ancak vecd yani exctasy durumunda mümkün olan bir şey olarak görünüyor. ${ }^{61}$

Vecd halindeki oyuncu, bir esrime halinde kendinden geçmiyor. Oyuncu; her an etkiye açık, her an uyanık, "gezgin". ${ }^{2}$ Arıcı, bir ek-stasis, kendinden çıkma, vecd tanrısı olan Dionysos'un aynı zamanda tiyatronun kökeni olmasının tesadüf olmadığını söylüyor. ${ }^{63}$ Sayın, ek-stasis yorumu ile dışarıya yönelik bir öznesi kalmayan oyuncunun bütün kimlikleri bedeninde oynatabilme olanağına işaret ediyor:

Kişinin kimliğini değil, kendine kapanışını, kendi yapıtsallı̆̆ını değil, sonluluğunu ve ölümlülü̆̈̈̈nü gözeten bir cemaati mümkün kılan, kendinden dışarl çıkmanın vecdin, ekstatis' 'in kendisidir. Ekstasis, kişinin kendi emeğinin bir ürünü olarak, bir yapıt olarak ortaya çıkmaz; kişinin mevsim gibi, aşk gibi başına gelen, onu bir başkası yapan, kendine sadece bir başkası olarak geri döndüren, sahip olmadı̆̆ bir şeyi asla sahip olmayacağı bir başkasına veren eserdir, alamettir, kendi duruşunun artık o duruş olmayan izidir. Vecde gelenin, dışarıya yönelik bir öznesi yoktur, kalmamıştır (...) “Ben öldüm” ifadesindeki ben, hiç kimse olmayı başarabildiği an, bedeninde bütün kimlikleri oynatabilen bir oyuncu gibi, özne olmanın, kendi olmanın, ayniyet sahibi olmanın dışına çıkabildiği, kendi sınırına dayanabildiği, ölmeden önce ölebildiği an gerçek bir cemaate açılabilir. Ölüm herkeste ortaktır, herkesin sinırıdır, herkesin vecde erdiği, çıktığı yer aynıdır. Gerçek olandır. Reeldir. Ölümdür. ${ }^{64}$

Oyunbaz oyuncu her daim "öznesiz bir özne" 65 olma arayışında. Oyunbazlık, kendini yıkmayı göze alabilen oyuncunun başkalığa ait olanları vücuda getirerek, gündelik uzamın içinde bir başkalığı yaratarak var olması. Oyunbaz oyuncu bu nedenle; her an kendi yıkımını gerçekleştirerek bedeninde bir başkasına dönüşebilme, başkasının biçimini alabilme, başkasının kılığıyla görünüşe gelebilme gücü ve yaratıcı edimi ile ele geçirilemez. Oyuncu, işte bu ele geçirilemezliği ile her şeye dönüşebilme gücünde Lacoue-Labarthe'a göre "mimesisin ve poetik olanın hediyesi" ni ${ }^{66}$ taşıyor. Dolayısıyla aktif mimesis Sayın’ın tabiriyle “(...) yıkılışını her an yeniden göze alan, hiçbir cemaate ait olmayanların oluşturduğu, ölümlülükleri dışında ölebilirlikleri ve öldürülebilirlikleri dışında hiçbir ortaklılıktan olmayanların kurduğu cemaat... Imkansızlı̆̆ın cemaati(...) ${ }^{967}$ ne dair bir yeri işaret ediyor. Oyuncu, bedeninde baştan bir özne

61 Oğuz Arıcı, "Maskeyle Varolmak”, Maske Kitabı içinde, Ed. Kerem Karaboğa, Oğuz Arıcı (İstanbul: Habitus Kitap, 2004), 25.

62 Ülgen, Kurmaca, Yanılsama: Oyunculuk, Deneyim, Hakikat Arasında, 150.

63 Arıc1, "Maskeyle Varolmak", 26.

64 Zeynep Sayın, Ölüm Terbiyesi (İstanbul: Metis Yayınları, 2017), 57-58.

65 Lacoue-Labarthe, "Diderot: Paradox and Mimesis", 264.

66 A.g.e., 259.

67 Sayın, Ölüm Terbiyesi, 36. 
varsaydığında ve onu sahiplendiğinde ise ele geçirilme tehlikesi taşıyor; Diderot'ya göre bu "bulaşıcı bir hastalık gibi" "68, Lacoue-Labarthe ise bunu "pasif mimesis" "69 olarak adlandırıyor. Ülgen'e göre ele geçirilme hali bir "güç düşmesi, algı tıkanması, oyunbazlı̆̆ın yitimi. "70 Aktif mimesis ise oyunbazlığa doğru "üretici ve biçimlendirici bir güç. "71

Teatral anlamda nötrlük arayışı, oyuncu bedeninin sonsuz olasılıkta ifadenin biçimini alabilmesine, oyunbazlığa, aktif mimesise doğru bir tür imkân halini alıyor. Nötr maske çalışmalarında oyuncu; sonsuz sayıda ifadeye, biçime, kılığa bürünme olanağına doğru önce gündelik hareket ve eyleme alışkanlıklarından sıyrılarak "nötr olanı temel alan" ᄁ2 bir hareket ve eylemlilik halini araştırıyor. Eylemi, eylemin dinamiğine dair her bir veçheyi tam ve eksiksiz şekilde gerçekleştiren oyuncu; eyleme, eylemin kendi dinamiği dışında başka bir sıfat, nitelik, duygu, ifade eklemekten kaçınıyor. Oyuncu bu sayede araştırdığı hareket ve eylemi, kendisinin ya da belirli bir kimsenin hareket ve eylemi olmaktan çıkararak hiç kimseye ve aynı zamanda herkese ait bir eylemlilik halinin peşine düşüyor.

Yürüme eylemi herkese ait fakat herkesin yürüyüş biçimi birbirinden farkl1. Herkese ait eylemlerin farklı bedenlerdeki yapılış biçimleri, tezahürleri birbirinden farklı. Bedenler birbirinden farklı, beden imkânları birbirinden farklı, yapabilirlikler birbirinden farklı. Lecoq; mutlak, evrensel, tek tip bir nötrlüğün olmadığının altını çiziyor. ${ }^{73}$ Bireyler hem birbirine benziyor hem birbirinden farklılaşıyor. ${ }^{74}$ Algının farklılığa kapanması oyuncu bedeninin uzama açıklığını, uzamı dinleme olanağını, sükûnetli beden halinin imkânlarını ıskalamasına neden oluyor; bedende bir sıkışma, etrafı, uzamı, başkalığı yok sayma riski doğuyor. Algının farklılıklara kapandığ 1 yerde bir tektipleştirme, tektipleştirmede ise "insanın sonsuz çoğulluğunun, farklılı̆̆ının tek bir insan gibi örgütlendirilmeye çalışıldı̆̆g” totalitarizm başl1yor. ${ }^{75}$ Oysa Lacoue-Labarthe'a göre mimesis "ister temsil, ister taklit, ister oyuncunun sanatı, ister diyalog yazımı" olsun, hepsinde kural aynı paradoks üzerine kurulu: "ne kadar benzer o kadar farklı". ${ }^{76}$ Ülgen'e göre insan aynı ki birbirini duyuyor, farklı ki birbirini dinliyor. ${ }^{77} \mathrm{Bu}$ nedenle oyuncunun karakter ve rol kişisiyle ilişkisindeki temel soruları her

68 Diderot'dan aktaran: Lacoue-Labarthe, "Diderot: Paradox and Mimesis", 264.

69 A.g.e., 264.

70 Ülgen, Kurmaca, Yanılsama: Oyunculuk, Deneyim, Hakikat Arasında, 254-255.

71 Lacoue-Labarthe, "Diderot: Paradox and Mimesis", 259.

72 Lecoq, Siirsel Beden, 54.

73 A.g.e., 37. Bu noktada tek tip bir "nötr beden" yanılsaması ile ilgili Evans, "nötr beden"in 'normal', 'ideal' bir beden algısı yaratarak engelli bedenler, toplumsal cinsiyet, sınıf, ırk bağlamında kültürel ve politik kodları beden üzerinden yeniden üretilebilir kılma riskini hatırlatıyor. Çalışmalarda doğal, güzel, ideal bir beden algısının endüstriyel ve kültürel anlamda inşa edildiğini her zaman hatırlatmanın ve hem beden hem 'hareket ve jest'in sosyopolitik önemine dair okumaları birlikte gerçekleştirmenin önemini vurguluyor. Mark Evans, Movement Training for The Modern Actor (New York: Routledge, 2009), 110-118.

74 A.g.e., 56.

75 Hannah Arendt, Totalitarizmin Kaynakları, çev. İsmail Serin (İstanbul: İletişim Yayınları, 2014), 245.

76 Lacoue-Labarthe, "Diderot: Paradox and Mimesis", 260.

77 Ülgen, Kurmaca, Yanılsama: Oyunculuk, Deneyim, Hakikat Arasında, 78. 
daim hem “eğer ben olsaydım?” hem de "benden farklı nasıl?". ${ }^{78}$ Oyuncunun arayış1 "bir aynılık, farklılık paradoksunda, başkalık". ${ }^{79}$

Oyuncu, nötr bir hareket ve eyleme halini araştırırken beden farklılıklarını yadsımadan, tüm farklılıkların yaratıcı gücü ile birlikte, bir olası ortaklığın peşine düşüyor. Oyuncu, her türlü hareket, eylem, nitelik ve sıfatı kendine ait olmaktan çıkararak "sahnedeki varoluşunu ve uzam algısını hissetmek için, bedeninin ve jestlerinin herkese ait olup olmadı̆̆ını, herkes tarafindan tanınabilir jestlerin ortak paydasını" ${ }^{80}$ araştırıyor. Oyuncu, herkese ait bir uyanış, herkese ait bir elveda, herkese ait bir yolculuk gibi temalarla çalışıyor.

Bütün bireylerin birbirine benzediği fikri aynı zamanda hem doğrudur hem de tamamen yanlıştır. Evrensellik tektiplik değildir. Bu konunun üzerindeki esrar bulutunu dağıtmak için gündelik hayatın özellikle gerçekçi ya da çok klişe melodramatik temaları üzerine çalışma yapmayı öneririm. Amacım bu temalarda bir nötrlük durumunun var olduğunu göstermektir. ${ }^{81}$

Çalışmalardan biri "Gemiye Elveda" teması. Tema, çok sevilen bir arkadaşın uzaklara gitmek üzere bir gemiye binmesi ve onu bir daha göremeyecek olmanın bilinciyle ona son bir elveda jesti göndermek için iskeleye doğru koşmayı içeriyor. Elveda gibi hem yaşayan hem şahit olan için tesiri oldukça kuvvetli bir temayı tüm bu ifade ve duygular yerine sadece hareketin kendisini icra ederek oynamak, oyuncunun yalnızca eylemin kendisini yapmakla ilişkilenmesine imkân sağlayarak ayrılık eylemini, “özel bir bağlamdan ve bir karakterle ilintili" 82 olmaktan çıkarıyor.

Her bir oyuncu herkese ait olanı nötr maskeyle hisseder; nüanslar işte o zaman güçlü bir şekilde ortaya çıkar. Bu nüanslar karakterlerden kaynaklanmazlar çünkü karakter yoktur. Bu nüanslar oyuncuların kendi aralarındaki mizaç farklılı̆̆ından kaynaklanır. Bedenler farklıdır ama o bedenleri bir araya getiren "elveda" teması üzerinden birbirlerine benzeşirler. ${ }^{83}$

Nötrlük; bir aynılık, farklılık zemininin an be an vuku bulduğu oyuncu bedeninde; farklılıkların yaratıcı gücüne, oyuncunun yaratıcı edimine, başkalığı vücuda getirmesine, ikiliğe doğru oyuncuya dayanak noktası oluşturan, "aslında var olmayan" ${ }^{84}$ bir hal. Oyuncunun nötrlük arayış1 "sadece bir teşebbüs." "85

78 A.g.e., 52-53.

79 A.g.e., 117.

80 Lecoq, Siiirsel Beden, 57.

81 A.g.e., 56.

82 A.g.e., 57.

83 A.g.e., 57.

84 Sears A. Elderge \& Hollis W. Huston, “Actor Training In The Neutral Mask”, The Drama Review 22 (1978), 21.

85 Lecoq, Şiirsel Beden, 37. 
Ülgen'e göre "boşlukta yaratıcıliğın dili, 'fiil”" ${ }^{86}$ Oyuncu; boşlukta fiiliyatla, eylemle yaratmaya başlıyor. Eyleme biçimini veren, eylemi bir başkasının eylemi haline getiren şey eylemin "nasıl yapıldığı” ile belirleniyor. Ülgen; oyuncunun eyleminin 'ne' olduğunun yanında 'nasıl' yapıldığı sorusunun aynı zamanda bir nitelik sorusu olduğunu söylüyor. ${ }^{87}$ Oyuncu, nötr bir eyleme haline eklediği niteliklerle eylemi biçimlendirmeye, eylemi bir kimsenin eylemi olmaya doğru dönüştürmeye başlıyor. Bir başka deyişle, artık kılık değiştirerek biçimlenmeye, bir başkasına dair bir uzam yaratmaya başlıyor oyuncu. Eski Türkçede kılık "hal ve tavır, davranış biçimi”, "yapmak, etmek" anlamındaki kılmak fiilinden türüyor. ${ }^{88}$ Kılık değiştirme; oyuncunun yaptıkça, eyledikçe değişen tavrı ve o tavrın hem halinde hem görünüşünde yarattığı başkalık. Oyunculuğun kendi doğasına dair, hiçbir dışarıdan müdahaleye (kostüm, makyaj, maske vb.) bağlı kalmaksızın oyuncunun bedeninde bir başkasına doğru başkalaşması; aynılık ve farklılıklarıyla bir başkasını imleyecek beden formu, bakışı, göz kırpışı, yürüyüşü, nefes alışı, 'o' sesi 'o' şekilde çıkarışı, 'o' kelimeyi 'o' şekilde söyleyişi, hareketin her türlü niteliği ve bu hareket etme biçiminin oluşturduğu bir beden maskesi, maskelenmiş bir beden olarak karşımıza çıkıyor. Oyuncu; yüzünü kapayacak somut bir maske olmadan tüm bedenini maskeliyor, kendi bedeninde bir başkasının kılığında ikamet ettiği bir karakteri, bir rol kişisini yaratıyor. Kılık değiştirme; oyuncunun, şimdi ve burada, bedeninde bir başkasının izlerini taşımaya başladığı ikilikte değişen, somut hiçbir nesne olmaksızın bedeninde kıpırdayan bir başkalık, açılmaya başlayan bir başkasına ait uzamın oyun imkânları, oyuncunun oyunbazlığı halini alıyor.

Oyuncunun kendi yokluğunda olduğu nötr bir zemin de oyun kişisinin bir başkasıyla bu bedende karşılaşmasına, kılık değiştirmesine, bir başka deyişle ikiliğe, oyunbazlığa doğru aidiyetsiz bir ara alana tekabül ediyor. Bu anlamda nötrlük; Lecoq pedagojisinde bulunan oyun maskelerinin çeşitleri için bir referans noktasını teşkil ediyor. Lecoq'a göre "her maskenin altında bütünün taşıyıcısı bir nötr maske” bulunuyor.

Nötr maske biricik bir maskedir, tüm maskelerin Maskesi'dir. Nötr maskeyi tecrübe ettikten sonra olabildiğince çok çeşitlilikte başka tür maskeler üzerine çalışırız ve hepsini "ifadeli maskeler" genel terimi altında toplarız. Nötr maske tek bir tane ise ifadeli maske sonsuz sayıdadır. ${ }^{89}$

Lecoq pedagojisinde oyuncu, nötr maskeden sonra larva maske, tam maske, yarım maske gibi ifadeli maskeler, Commedia dell'Arte maskeleri, grotesk ve bufon gibi beden maskeleri ve en küçük maske olan kırmızı burun (clown) ile bedenin komedi olanaklarını araştırmaya, önce nötr maskeyi, bir başka deyişle aidiyetsiz ara alanı deneyimleyerek geçiyor.

86 Ülgen, Kurmaca, Yanılsama: Oyunculuk, Deneyim, Hakikat Arasında, 45.

87 A.g.e., 45

88 "Kılık" kelime anlamı, İnternet Erişimi: http://www.lugatim.com $/ \mathrm{s} / \mathrm{k} \% \mathrm{C} 4 \% \mathrm{~B} 11 \% \mathrm{C} 4 \% \mathrm{~B} 1 \mathrm{k}$.

89 Lecoq, Şiirsel Beden, 70. 
Muhafaza edilen aralıkta, boş alanda aynı zamanda mizahın serinliği var diyor Ülgen..$^{90}$ Ara alanın ve ikiliğin muhafazasında oyunbazlık, oyunbazlığın kendisinde ise açığa çıkmaya kadir bir komedi imkânı var. Baudelaire'e göre komiği gerçekleştirenler, "kendi varlıklarını bilmezden gelenler":

Gülünç özellikle gülende, izleyicide var olan bir şey. Ama ne ki, kendilerinde gülünç duygusunu geliştirmeyi ve bunu başkalarını eğlendirmek için kullanmayı meslek edinmiş kiş̧iler bunun dışındadır. Çünkü onlar belli bir süre kendi varlıklarının bilincinde olmama kuralına uyarlar, kendi varlıklarını bilmezlikten gelirler; bu süreçte hem kendileri hem başkaları olurlar. Böylesi bir şey, insandaki sürekli bir ikiciliğin varlığını, insanın hem kendisi hem başkası olabilme gücünü gösteren tüm sanatsal olgularda yer alır. ${ }^{91}$

Aidiyetsiz bir ara alanda kendi yokluğunu oynayan, kendi varlığını bilmezden gelen ne kendisini ne bir başkalığı taşıyan oyuncunun; başkalığı karşılayışında, vücuda getirişinde, değişen biçiminde, büründüğü kılıkta, ikilikte bir komedi imkânı var. Güray Dinçol, nötr maske ile yapılan tematik çalışmalarda bedenin psikosomatik özelliklerinin ortaya çıkması ve vurgulanmasıyla olağan akışta bir kırılma yaratıldığını; bedenin komedi potansiyelini görmeye, fark etmeye dair bir kapı aralandığını belirtiyor. ${ }^{92}$ Potansiyellik, olmaya da olmamaya da eşit mesafede diyor Sayın. ${ }^{93}$ Nötr zemin; içinde sürekli bir başkalaşım ve dönüşüm imkânını taşıyan oyuncu bedeninin komedi potansiyelinden bahsetmemize bir imkân sağlıyor. "Kılık değiştiren bir kişi komiktir." diyor Bergson. ${ }^{94}$

Lecoq, pedagojisinin çerçevesini nötr maske ile komik varyete (bürlesk, absürt, ekstantrik vb biçimler) ve clown çalışmalarının oluşturduğunu söylüyor. ${ }^{95}$ Pedagoji nötr maske ile başlıyor ve "kişinin naifliğini ve kırılganlığını ortaya çıkarmaya izin veren"96 en küçük maske kırmızı burun ile son buluyor. Dinçol, nötr maske çalışmaları sırasında; oyuncunun nötr eylem araştırmasında psikosomatik özelliklerinin ortaya çıkarak bir kılığa bürünmeye başlaması ve bedenin komik potansiyelinin açığa çıkması ile birlikte oyuncuya kırmızı burun taktırarak en küçük maskenin, clownun oyun uzamında bir deneme yaptırıyor. ${ }^{97}$ Lecoq'a göre clown, nötr maskenin anti tezi. ${ }^{98}$ Oyuncu nötrlük arayışında ne kendisi ne bir başkalığı taşıdığı bir beden seviyesinin peşindeyken, clown stilinde kendi beden malzemesinin, kendi komiğinin üzerinde çalışıyor. Lecoq pedagojisinde clown, nötr maskeden sonra ifadeli maskeler ve beden maskeleri ile yapılan oyun araştırmasının

90 Ülgen, Kurmaca, Yanılsama: Oyunculuk, Deneyim, Hakikat Arasında, 76.

91 Charles Baudelaire, Gülmenin Özü, Çev. İrfan Yalçın, (İstanbul: İris Yayınları, 1997), 27.

92 Güray Dinçol, "Neye Güleriz? Oyunculuk Atölyesi”, Yayınlanmamış Atölye Notları (İstanbul: 2019).

93 Sayın, Ölüm Terbiyesi, 156.

94 Henri Bergson, Gülme: Komiğin Anlamı Üstüne Deneme, çev. Yaşar Avunç (İstanbul: Ayrıntı Yayınları, 2015), 36.

95 Lecoq, Şiirsel Beden, 165.

96 A.g.e., 167.

97 Güray Dinçol, "Şiirsel Komedi: Bir Clown Araştırması Oyunculuk Atölyesi”, Yayınlanmamış Atölye Notları (İzmir: 2019).

98 Lecoq'tan aktaran: Murray, Jacques Lecoq, 73. 
ardından oyuncunun kendi malzemesinin oyunu, kendi bedeninin maskelenmesi, kendi kıllı̆g1, komiği olarak karşımıza çıkıyor. Bu nedenle Lecoq'a göre oyuncunun “kendi clownunu arayışı öncelikle kendi gülünçlügü̈nün arayışı". ${ }^{99}$ Lecoq, clown stilinde oyuncunun zayıflıklarını gösterdiği ölçüde komik olacağını söylüyor. ${ }^{100}$ Dinçol'a göre clown, "hata ve başarısızlı̆̆a dair bir güzelleme”. ${ }^{101}$ Zupančič, örneğin dilsel bir 'hata'ya, 'kusur'a gülünmesini; onu düzeltmek, ıslah etmek ile değil, aksine 'hata'nın barındırdığı başarısızlığın, anlamsızlığın "mucizevi" biçimde yarattığ 1 artı-anlam ile, "hiçten" ortaya çıkan bir düşünce ve ruh ile ilişkilendiriyor. ${ }^{102}$ Ülgen, komedinin “hataya, kusurlu olana sevgi ve şefkat duyabilmek ile alakall” olduğunu söylüyor. ${ }^{103}$ Oyuncunun kendi gülünçlüğü üzerine çalışabilmesi, kendine dışarıdan bakabileceği bir ikili bakışı, öznesizliğe gönüllü bir oyunbazlık arayışını ve dolayısıyla aidiyetsiz ara alanın muhafazasını talep ediyor; var oluşun kendisine gülebilme olanağını doğuruyor.

Oyunbaz oyuncu; bir başkasının/bir başkalığı vücuda getirişinde, ikiliği taşıyışında, ikilikteki komedi imkânında mevcut biçimi yıkıma uğratarak tıpkı Dionysos gibi verili olanın görünüşünü tepetaklak ediyor:

Dionysos tecellisi sadece biçimlerin sınırlamalarının, görünür dış hatların dışında kalmakla yetinmez. Tüm görünüşleri bozan bir sihir, bir maya şeklinde yansır. Aşina olunan nesnelerin, güven verici şekillerin istikrarlı dünyası nerede, sarsılıp, yanılsamanın, imkânsızın, saçmanın gerçeklik sayıldığı bir düşlem oyunları dünyası nerede kurulsa, Dionysos oradadır. ${ }^{104}$

Bahtin, Ortaçağ karnavallarında taklit ve kılık değiştirme aracılığı ile gerçekleşen komik ritüeller ile hiyerarşik düzenin ters yüz edildiğini belirtiyor. Örneğin “Deliler bayramı”nda soytarılar, kral ve diğer din adamlarının yerine geçiyor. ${ }^{105}$ Komedi, Zupančič’in deyimiyle “makullükten bütünüyle uzak bir ısrar"106, makul kabul edilenin bir anlık tepetaklaklığı, ters yüz edilişi. Kılık değiştirmenin komedi potansiyeli ile gözde ve gözle görünende yaratılan tepetaklaklık; bakışın kendisinde, kendi öğrenilmiş perspektifinde bir sarsılma yaratarak bir diğer imkânının görül(n)ebilirliğini de beraberinde getiriyor. "Dünyanın ortasında dururmuş oyuncu, ortadan hareketle yürüyerek evreni başkalaştırmaya kadirmiş. " 107 diyor Sayın. Oyuncu, her an başka bir kılıkla görünüşe gelmeye kadir oluşuyla gündeliğin yarığından çıkabilecek bir başka imkânı barındırıyor. Ara alan, oyuncunun yaratmaya kadir olduğu başkalıklar ile alışılmış gündeliğin verili gerçekliği ile oynadığı, onu bir anlık ters yüz ettiği, gündelik dışı uzama doğru yaratıcı edimin başlangıcı halini alıyor.

99 Lecoq, Şiirsel Beden, 167.

100 A.g.e., 168.

101 Dinçol, "Şiirsel Komedi: Bir Clown Araştırması Oyunculuk Atölyesi".

102 Alenka Zupančič, Komedi: Sonsuzun Fiziği, çev. Tuncay Birkan (İstanbul: Metis Yayınları, 2009), 117.

103 Tulû Ülgen, "Studio Oyuncuları: Gerçekçi Sahneleme Dersi", Yayınlanmamış Ders Notları, (İstanbul: 2016).

104 Vernant, Eski Yunan'da Mit ve Tragedya, 533.

105 Mikhail Bahtin, Karnavaldan Romana, çev. Cem Soydemir (İstanbul: Ayrıntı Yayınları, 2014), 102.

106 Zupančič, Komedi: Sonsuzun Fiziği, 208.

107 Anhui dansı ve Luo diyagramından hareketle Sayın, "Kurmaca/yanılsama: metnin düşündürdükleri”, 5. 
Latife, misal alemine açılmak diyor Ülgen. ${ }^{108}$ Misal; olanın kendisinden bir başka olasılığın, başka olanakların, mevcut durumu yaşayıştaki bir başka ihtimalin, başka bir imkânın olabilirliğine dair. Zupančič komedinin ölümü, acıyı, insanın içinden çıkışı olmayan "korkunç" durumlar içinde bulunmasını reddetmediğini bunun yerine "biz konuşurken de, yani hayatımızın her anında hayatımıza ait bir şeylerin kendi hayatlarını yaşadı̆̆ına dikkatimizi” çektiğini belirtiyor. ${ }^{109}$ Hayatın zor zamanlarında bir direniş biçimi olarak ortaya çıkan komedinin; çift değerli bir öznellik alanına sahip olduğunu; insanı verili olana katlanır hale getirerek bir yanılsama işlevi görebileceği gibi aynı zamanda değişim imkânını ortaya çıkaran bir “oyun zemini” yarattığını söylüyor:

Nitekim komedinin koruyup ayakta tutmamıza yardımcı olabileceği öznellik alanı, şüphesiz, çiftdeğerlidir. Son kertede verili durumun veya düzenin baskıcıllğıın ayakta tutmaya yardım eden çünkü onu katlanılır hale getirip insanın içinde fiilen özgür kalabileceği yanılsamasını besleyen o mesafe işlevini görebilir. Ama öte yandan tam da her türlü olası değişimin gerçekleşebileceği oyun zeminini [playground] ${ }^{110}$ kuran ve bu değişim sirasinda seferber edilen fazladan, boş bir öznellik imkânı da olabilir. ${ }^{11}$

Oyuncunun mimetik eylemi; aidiyetsiz bir ara alanda, sonsuz olasılıkta biçime, kılığa bürünebilme imkânı ve gücünde var olan komedi potansiyeliyle, bir anın içinde, insanın içinde barındırdığ bin bir olasılığ 1 , alışılmış gündeliğin içinde açtığı gündelik dışı uzamda bir başkalığın mümkünlüğünü, olanın olduğundan başka olma ihtimalini, bir yanılsamayla değil, yarattığı oyun zeminiyle, her an içinde taşıdığı ikili bakışla hatırlatıyor.

Oyuncunun, bir başkalığı/bir başkasını vücuda getirmesine doğru, bir tür başlangıç zemini olarak nötrlük arayışı; gerilimsiz, sükûnetli, oyuncunun uzamdaki mevcudiyetini kuvvetlendiren bir beden açıklığına, hiçbir niteliği kendine ait hale getirmeden hiç kimseye ve herkese dair eyleme halinin peşinde olan bir beden seviyesine, hiçbir niteliğin mülk edinmediği anda başlayan her şeye dönüşebilme imkânına, bu imkânın içinde taşıdığı ikiliğe ve ikilikteki komedi potansiyeline dair yaşam ve oyun arasında, oyuncunun kendi yokluğunu oynadığı bir ara alana, mütemadiyen süren bir arayış sürecine, "asla sonu gelmeyen bir araştırma"112 ya tekabül ediyor.

108 Ülgen, Kurmaca, Yanılsama: Oyunculuk, Deneyim, Hakikat Arasında, 119.

109 Zupančič, Komedi: Sonsuzun Fiziği, 208.

110 Metnin orijinal dilinde "playground" olarak geçiyor, çevirmen metinde "zemin" olarak ele almış, "oyun zemini” olarak çevirdim.

111 A.g.e., 208.

112 Elderge ve Huston, “Actor Training In The Neutral Mask”, 25. 
Peer-review: Externally peer-reviewed.

Conflict of Interest: The author has no conflict of interest to declare.

Grant Support: The author declared that this study has received no financial support.

Hakem Değerlendirmesi: Dış bağımsız.

Çıkar Çatışması: Yazar çıkar çatışması bildirmemiştir.

Finansal Destek: Yazar bu çalıșma için finansal destek almadığını beyan etmiștir.

\section{KAYNAKÇA / BIBLIOGRAPHY}

Arıc1, Oğuz, "Maskeyle Varolmak”, Maske Kitabı. Editör: Kerem Karaboğa, Oğuz Arıc1, 21-28. İstanbul: Habitus Yayıncılık, 2014.

Arendt, Hannah. Totalitarizmin Kaynakları, çev. İsmail Serin (İstanbul: İletişim Yayınları, 2014)

Barba, Eugenio ve Savarese, Nicola. Oyuncunun Gizli Sanatı: Tiyatro Antropolojisi Sözlüğü. çev. Ayşın Candan, Tarhan Onur, Aslı Seven. İstanbul: İstanbul Bilgi Üniversitesi Yayınları, 2017.

Baudelaire, Charles. Gülmenin Özü, Çev. İrfan Yalçın. İstanbul: İris Yayınları, 1997.

Bahtin, Mikhail. Karnavaldan Romana, çev. Cem Soydemir. İstanbul: Ayrıntı Yayınları, 2014.

Bergson, Henri. Gülme: Komiğin Anlamı Üstüne Deneme, çev. Yaşar Avunç. İstanbul: Ayrıntı Yayınları, 2015.

Diderot, Denis. Aktörlük Hakkında Aykırı Düşünceler, çev: Sabri Esat Siyavuşgil. İstanbul: Sosyal Yayınları, 1996.

Dinçol, Güray. "Şiirsel Komedi: Bir Clown Araştırması Oyunculuk Atölyesi”, Yayınlanmamış Atölye Notları. İzmir: 2019.

Dinçol, Güray. "Neye Güleriz: Oyunculuk Atölyesi”, Yayınlanmamış Atölye Notları. İstanbul: 2019.

Eldredge, Sears A. ve Huston, Hollis W, “Actor Training In The Neutral Mask”, The Drama Review 22 (1978): 19-28.

Euripides. Bakkhalar, çev. Sabahattin Eyüpoğlu. İstanbul: İş Bankası Kültür Yayınları, 2010.

Evans, Mark. Jacques Copeau. New York: Routledge, 2006.

Evans, Mark. Movement Training for The Modern Actor. New York: Routledge, 2009.

Feral, Josette ve Bermingham, Ronald P. "Theatricality: The Specificity of Theatrical Language”, SubStance 98/99 (2002), 94-108.

Huizinga, Johan. Homo Ludens, çev. Mehmet Ali Kılıçbay. İstanbul: Ayrıntı Yayınları, 2015.

Lacoue-Labarthe, Philippe. "Diderot: Paradox and Mimesis”, Typography: Mimesis, Philosophy, Politics, 248-266. Stanford: Stanford University Press, 1989.

Lecoq, Jacques. Theatre of Movement and Gesture. New York: Routledge, 2006.

Lecoq, Jacques. Şiirsel Beden, çev. Mine Çerçi. Ankara: Nota Bene Yayınları, 2015.

Karaboğa, Kerem. “Copeau'dan Terzopoulos’a Oyuncu ve Maske”, Maske Kitabı. Editör: Kerem Karaboğa, Oğuz Arıc1, 94-107. İstanbul: Habitus Yayıncıl1k, 2014.

Murphy, Maiya. Enacting Lecoq: Movement in Theatre, Cognition, and Life. Switzerland: Palgrave Macmillan, 2019. 
Murray, Simon. Jacques Lecoq. New York: Routledge, 2003.

Rozik, Eli "Mask and Disguise in Ritual, Carnival and Theatre”, South African Theatre Journal 11/1 (1997), 183-198.

Rudlin, John. Commedia dell'Arte: Oyuncular için El Kitabl, çev. Ezgi İpekli. İstanbul: Mitos Boyut Yayınları, 2000.

Rudlin, John. "Jacues Copeau: The Quest For Sincerity", Twentieth Century Actor Training, Editör: Alison Hodge, 55-79. New York: Routledge, 2000.

Sayın, Zeynep. Imgenin Pornografisi. İstanbul: Metis Yayınları, 2015.

Sayın, Zeynep. Ölüm Terbiyesi. İstanbul: Metis Yayınları, 2018.

Sayın, Zeynep. "Kurmaca/yanılsama: metnin düşündürdükleri”, Kurmaca, Yanılsama: Oyunculuk, Deneyim, Hakikat Arasında içinde 5-9. İstanbul: SubPress Yayıncılık, 2018.

Sennett, Richard. Ten ve Taş, çev. Tuncay Birkan. İstanbul: Metis Yayınları, 2014.

Ülgen, Tulû. Kurmaca, Yanılsama: Oyunculuk, Deneyim, Hakikat Arasında. İstanbul: SubPress Yayınc1lık, 2018.

Ülgen, Tulû. "Studio Oyuncuları: Gerçekçi Sahneleme Dersi”, Yayınlanmamış Ders Notları. İstanbul: 2016.

Vernant, Jean-Pierre ve Vidal-Naquet, Pierre, Eski Yunan'da Mit ve Tragedya, çev. Sevgi Tamgüç, Reşat Fuat Çam. İstanbul: Kabalcı Yayınları, İstanbul, 2012.

Zupančič, Alenka, Komedi: Sonsuzun Fiziği, Çev. Tuncay Birkan, İstanbul: Metis Yayınları, 2011. 